\title{
Effect of plant growth-promoting bacteria and inoculation media in the yield on cooksfoot yield
}

\begin{abstract}
Aguilar-Benítez, G. ${ }^{1}$, Castro-Rivera, R. ${ }^{2 *}$, Villegas-Aparicio, Y. ${ }^{3}$, Solís-Oba, M. M. ${ }^{2}$, Pacheco-Ortíz, J. A. ${ }^{2}$, Villarreal-González, J. A. ${ }^{4}$
${ }^{1}$ Instituto de Investigación de Zonas Desérticas, Universidad Autónoma de San Luís Potosí,

${ }^{2}$ Instituto Politécnico Nacional, Centro de Investigación en Biotecnología Aplicada, ${ }^{3}$ Instituto Tecnológico del Valle de Oaxaca, División de estudios de posgrado, ${ }^{4}$ Facultad de Medicina, Veterinaria y Zootecnia. Benemérita Universidad Autónoma de Puebla.
\end{abstract}

*Corresponding Author: rcastror@ipn.mx

\begin{abstract}
Objective: To determine the effect of three PGPB bacteria (Ewingella americana, Bacillus simplex and Microbacterium ginsengiterrae) and three inoculation media (digestate, compost and cornstarch) on plant height, leaf temperature, stalk density, morphological composition, and dry matter yield of orchard grass.
\end{abstract}

Design/Methodology/Approach: A completely randomized design was used, with a factorial arrangement $4 \times 3$, the experimental units being a pot with five initial stalks.

Results: The dry matter did not show difference between treatments with bacteria $(P>0.05)$, but the control the values increased up to $50 \%$. Compost and digestate media outperformed cornstarch by $22 \%$. The inoculation media had an effect $(\mathrm{P}<0.05)$ on the yield and leaf variables, while the bacteria promoted the formation of new stalks and the production of biomass, and reduced the leaf temperature.

Findings/Conclusions: Compost and digestate as inoculation media can notably favor the beneficial effect of $M$. ginsengiterrae, which was the one that registered the best yields.

Keywords: Dactylis glomerata, Ewingella americana, Bacillus simplex, Microbacterium ginsengiterrae.

\section{INTRODUCTION}

Plant growth-promoting bacteria (PGPB) are a group of microorganisms that, under specific conditions, - 21 activate direct and indirect mechanisms for improving radicular development or modifying the metabolism of plants in order to increase plant growth and productivity (Gragueda-Cabrera et al., 2012). The positive effect of bacterial inoculation in crop production has been widely demonstrated, because in direct association with the plant, the bacteria create favorable conditions for the exchange of beneficial metabolites for the plant and vice

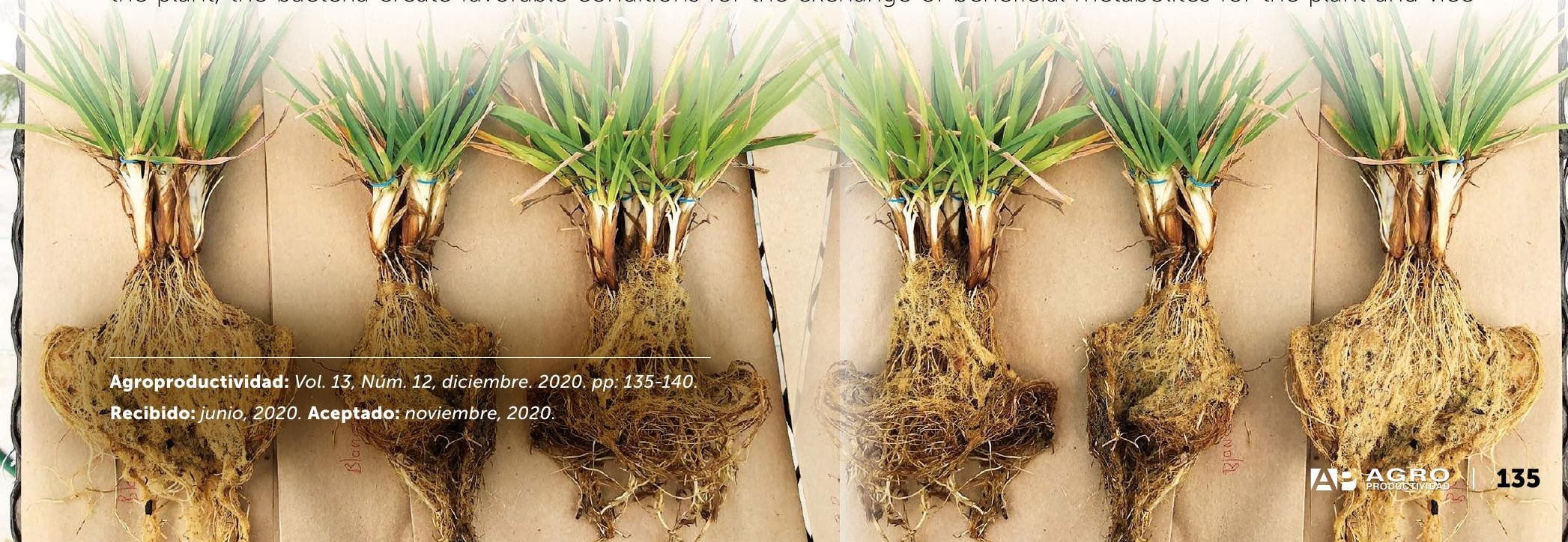


versa, in addition to improving soil structure, reducing compaction, increasing porosity, improving water filtration, and intervening in nutrient cycles (PérezMontaño et al., 2014; Menna et al., 2017; Singh et al., 2017). In this way, they have been considered to be an agricultural alternative to increase the yield of crops while conserving or even increasing the functional biodiversity of the soil (Alori et al, 2017; Planes-Leyva et al., 2004).

Several studies have shown that inoculation of grasses with Azospirillum spp. promotes the yield of dry matter, resulting in an increase in sprouting percentage, plant height, biomass, and grain yield in different proportions. For example, sorghum grain yield has been reported to increase up to 55\% compared to the same crop fertilized with $240 \mathrm{~kg} \mathrm{~N} \mathrm{ha}^{-1}$ (Rangel et al., 2014).

In Mexico, information on the effect of plant growthpromoting bacteria in forage production is scarce. Therefore, the objective of this study was to evaluate the effect of different inoculation media and PGPB bacteria on height, SPAD units, leaf temperature, botanical composition, and dry matter yield of orchard grass (Dactylis glomerata L.) under greenhouse conditions.

\section{MATERIALS AND METHODS}

The experiment was conducted under greenhouse conditions in the Center for Research in Applied Biotechnology (CIBA) of the Instituto Politécnico Nacional (IPN), located in Tepetitla de Lardizábal, Tlaxcala (19 16' 55.17" N, $98^{\circ} 21^{\prime}$ 57.59" W; 2222 masl). The inoculation media used were prepared in the following manner:

Compost. This substrate was sterilized in an autoclave three times every other day. The necessary inoculum was added to 40 grams of compost to adjust to a concentration of $1 \times 10^{8} \mathrm{CFU}$ per $\mathrm{g}^{-1}$. It was divided into aliquots of one gram in sterile $1.5 \mathrm{~mL}$ tubes and one aliquot was used per pot. The control consisted of one gram of compost without inoculum.

Corn Starch. During 5 days, $40 \mathrm{~mL}$ of bacterial inoculum were lyophilized with a concentration of $1 \times 10^{8} \mathrm{CFU}$. Afterwards, $0.04 \mathrm{~g}$ of lyophilized inoculum were taken and mixed with $0.1 \mathrm{~g}$ of corn starch. This mixture was applied to the soil of each experimental unit.

Digestate. This medium was diluted to $50 \%$ with distilled water and $20 \mathrm{~g} \mathrm{~L}^{-1}$ of sucrose was added as a source of carbon, previously sterilized in an autoclave. Later, $40 \mathrm{~mL}$ of the necessary inoculum was mixed in to a concentration of $1 \times 10^{8} \mathrm{CFU}$ per $\mathrm{mL}$ of digestate. The mixture was distributed in aliquots of $1 \mathrm{~mL}$, to apply one aliquot to each pot. The control was sterilized digestate without bacteria.

The bacterial strains used in this study were previously identified through 16s RNAr sequencing and correspond to the species Ewingella americana, Bacillus simplex and Microbacterium ginsengiterrae.

The media and substrates were sterilized in a Prado brand autoclave, model AH-80170.

The orchard grass seeds (Dactylis glomerata L.) were donated by the forage laboratory of Colegio de Postgraduados. The inoculation media used were: 1) digestate, donated by the Universidad Autónoma Chapingo; 2) compost, donated by the Zacatenco Composting Unit of the Instituto Politécnico Nacional (IPN); 3) commercial-brand corn starch, sterilized in an autoclave; and a sandy Fluvisol soil was used as a substrate in the experimental units, obtained from the experimental plot of the Center for Research in Applied Biotechnology (CIBA) of the IPN Tlaxcala Unit.

The treatments and experimental units were distributed according to a completely random design with a $4 \times 3$ factorial arrangement, where the factors were: inoculum ( 3 strains of bacteria and the control) and inoculation medium (digestate, corn starch, and compost). The values obtained in the experimentation phase were graphed in SigmaPlot V.10.0 (2015) and the statistical analyses were carried out using the GLM procedure of the SAS ${ }^{\circledR}$ Version 9.0 for Windows ${ }^{\circledR}$ (2002) statistical software. The treatment means were compared using the Tukey test at a significance level of $5 \%$.

The control treatments were: one gram of compost and $0.1 \mathrm{~g}$ of corn starch and digestate; all without bacterial inoculation.

The experimental unit was a pot with $1.5 \mathrm{~kg}$ of soil, containing five stalks of orchard grass, each 45 days old. At the experiment start, the stalks were uniformly cut at a height of $5 \mathrm{~cm}$ to reduce the effect of covariables, and the solid media were inoculated with the PGPB bacteria and directly applied to the rhizosphere zone. 


\section{Evaluated Variables}

Plant Height. Once 70 days passed since the homogenizing cut, the height of each grass cluster per pot was measured with a $30 \mathrm{~cm}$ graduated ruler at precision of $0.1 \mathrm{~cm}$, with the ruler positioned vertically from the base of the plant to the top youngest leaf (Castillo et al., 2009).

Leaf Temperature. The datum was recorded from the upper leaves with differentiated ligule, with a Spectrum Technology Inc ${ }^{\circledR}$ brand infrared thermometer.

Morphological Composition. The harvested forage was separated into its morphological components: leaf (from the base of the ligule to the leaf apex), and stalk (the pseudostalks and leaf veins were included).

Dry Matter Yield. The harvested forage was weighed fresh and then dried in a forced air oven at $70{ }^{\circ} \mathrm{C}$ for 48 hours. Finally, the dried samples were weighed in an analytical balance.

Density or Number of Sprouted Stalks. Before the final cut, the stalks of each pot were counted using a plastic ring to identify them, and the initial amount of 5 stems per pot was subtracted from the total count.

\section{RESULTS AND DISCUSSION}

Concerning plant height, the control presented the lowest value $(P<0.05)$ compared to the rest of the treatments. The inoculation medium did not affect ( $P>0.05$ ) plant height (Table 1). After analyzing the results per treatment in detail, differential performances were observed. While Bacillus simplex and Ewingella americana promoted greater plant height when inoculated with compost, Microbacterium ginsengiterrae showed better performance when inoculated with digestate (Figure 1D). The leaf temperature with $M$. ginsengiterrae was lower $(\mathrm{P}<0.05)$ compared to Bacillus simplex, Ewingella Americana and the control (Table 1). The inoculation medium did not affect this variable $(P>0.05)$. Likewise, it was observed that without inoculation (control) and with corn starch, the leaf temperature was higher $(P<0.05)$ compared to the digestate, which showed the lowest values (Figure 1E).

Morphological Composition. The weight of the dry stalks was different $(P<0.05)$ with the control; however, there was no difference between the bacterial treatments $(P>0.05)$, although quantitively the highest value was seen in treatments with Microbacterium and Ewingella. The inoculation medium did not have a major effect ( $P>0.05)$. By treatment, the Bacillus simplex inoculated with the corn starch medium showed the maximum values for dry weight of stalks (Figure 1A).

Concerning the dry weight of leaves, there were differences as a result of bacteria and the cultivation medium $(P<0.05)$. The maximum weight was obtained with $M$. ginsengiterrae and B. simplex and the minimum,

\begin{tabular}{|c|c|c|c|c|c|c|}
\hline Factor & $\begin{array}{c}\text { Stem } \\
\text { accumulated }\end{array}$ & $\begin{array}{c}\text { Stem } \\
\left(\text { g DM pot }^{-1}\right)\end{array}$ & $\begin{array}{c}\text { Dry matter } \\
\left.\text { (g DM pot }^{-1}\right)\end{array}$ & $\begin{array}{c}\text { Leaf } \\
\left.\text { (g DM pot }^{-1}\right)\end{array}$ & $\begin{array}{l}\text { Leaf Temp. } \\
{ }^{\circ} \mathrm{C}\end{array}$ & $\begin{array}{l}\text { Height } \\
(\mathrm{cm})\end{array}$ \\
\hline \multicolumn{7}{|l|}{ Bacterias } \\
\hline M. ginsengiterrae & $7.8 \mathrm{~A}$ & $1.81 \mathrm{~A}$ & $3.07 \mathrm{~A}$ & $1.26 \mathrm{~A}$ & $23.3 \mathrm{~B}$ & $7.2 \mathrm{AB}$ \\
\hline B. simplex & $7.7 \mathrm{~A}$ & $1.5 \mathrm{~A} A B$ & $2.61 \mathrm{~A}$ & $1.03 \mathrm{AB}$ & $24.9 \mathrm{~A}$ & $7.5 \mathrm{~A}$ \\
\hline E. americana & $5.4 \mathrm{AB}$ & $1.62 \mathrm{~A}$ & $2.62 \mathrm{~A}$ & $1.0 \mathrm{BC}$ & $25.4 \mathrm{~A}$ & $7.5 \mathrm{~A}$ \\
\hline Control & $4.1 \mathrm{~B}$ & $1.07 \mathrm{~B}$ & $1.84 \mathrm{~B}$ & $0.77 \mathrm{C}$ & $26.5 \mathrm{~A}$ & $6.1 \mathrm{~B}$ \\
\hline \multicolumn{7}{|c|}{ Inoculation method } \\
\hline Lyophilized & 5.3 & 1.38 & $2.2 \mathrm{~B}$ & $0.83 \mathrm{~B}$ & 24.7 & 6.6 \\
\hline Digestate & 7.3 & 1.67 & $2.75 \mathrm{~A}$ & $1.1 \mathrm{~A}$ & 24.4 & 6.9 \\
\hline Compost & 6.2 & 1.45 & $2.64 \mathrm{~A}$ & $1.19 \mathrm{~A}$ & 25.2 & 7.5 \\
\hline \multicolumn{7}{|l|}{ Significance } \\
\hline Strain & $\star *$ & $\star *$ & $\star \star$ & $\star \star$ & ** & $\star \star$ \\
\hline Méthod & NS & NS & ** & ** & NS & * \\
\hline$C * M$ & NS & NS & ** & ** & NS & NS \\
\hline
\end{tabular}

Different capital letters in columns are statistically different Tukey $(P<0.05)$. Significance; NS=Non-significant; ${ }^{*}=0.05$; $\star \star=0.01$. 


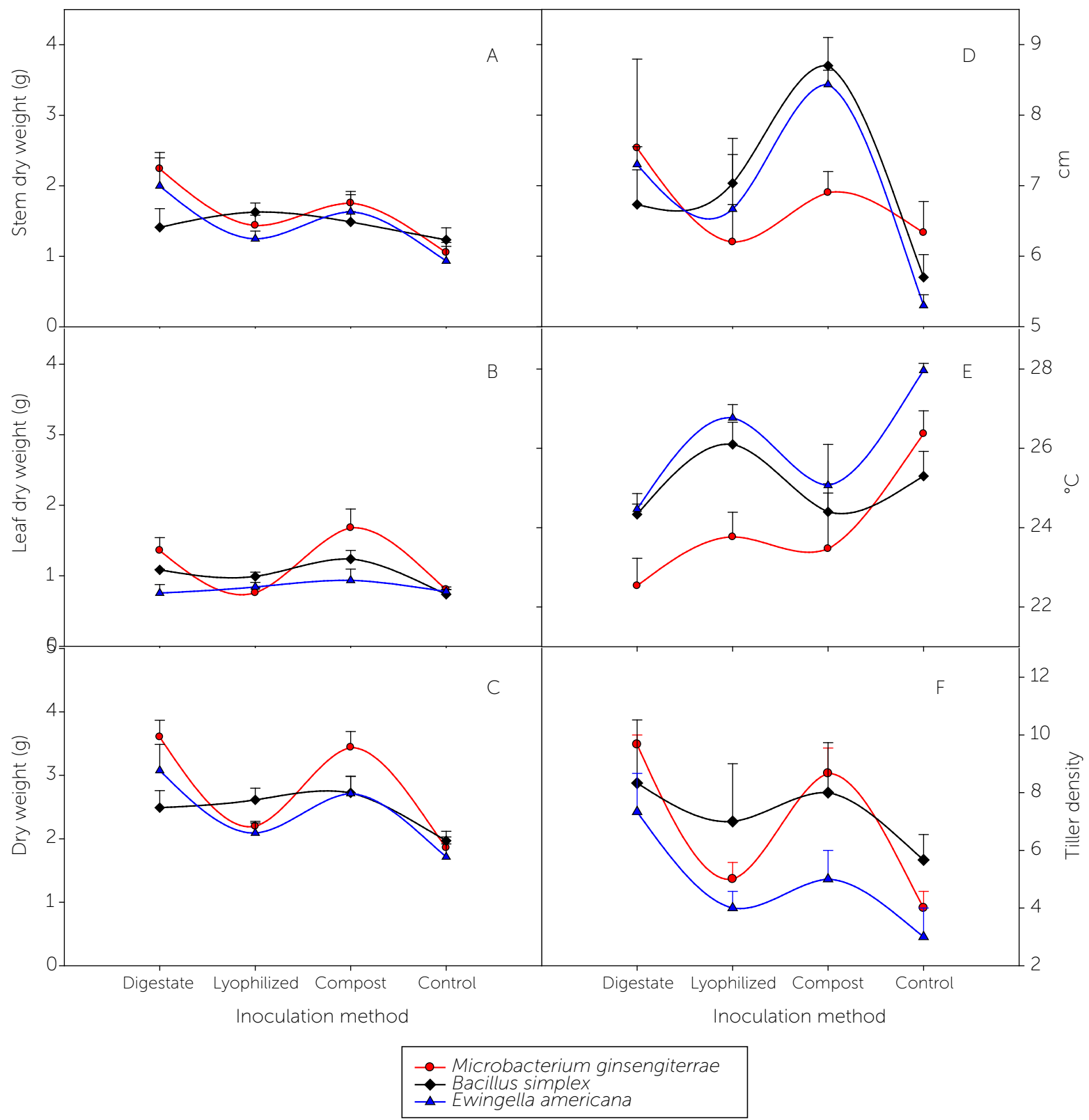

Figure 1. Dry weight of stalk or pseudo-stalk (A), dry weight of leaf (B), total biomass (C), plant height (D), leaf temperature (E), SPAD units (F) of orchard grass inoculated with PGPB bacteria and different inoculation media.

with the control; although there was no difference with compost and digestate, the minimum value was obtained with corn starch (Figure 1B). In addition, a significant effect was observed in the interaction between bacteria and inoculation medium (Table 1).

The total dry weight demonstrated that, except for the control, there was no difference in the rest of the treatments with bacteria $(P<0.05)$. An increase of up to $50 \%$ more of total dry matter was achieved with the bacteria, compared to the control; while the compost and digestate surpassed corn starch by $22 \%(P<0.05)$. The effect of the principal factors (Strain and Method) and their interaction was highly significant $(P<0.01)$ (Table 1). Figure $1 \mathrm{C}$ shows that, when using compost and digestate, M. ginsengiterrae and E. Americana produced a greater amount of dry matter than when using corn starch.

Accumulated Stalks. The values obtained show that the clusters inoculated with M. ginsengiterrae and B. simplex showed different values ( $P<0.05)$, achieving up to $150 \%$ more stalks $(P<0.05)$ compared to the initial population (5 stems per pot). With E. americana and the control, up to $90 \%$ more stalks were obtained, without differences $(P>0.05)$ between these treatments (Figure 1F). As a main 
factor, the inoculation media did not show any effect on this variable (Table 1).

Forage grasses have demonstrated that their growth depends on the interaction of climate factors as well as the management of the frequency and severity of defoliation (Hernández-Garay et al., 1997; McKenzie et al., 1999). In the present experiment, orchard grass was evaluated in the same environmental conditions, modifying only a small proportion of soil microorganisms. Therefore, it is evident that the bacteria and the inoculums had a significant effect on the evaluated variables.

The differential reactions in the yield of orchard grass can be attributed to the fact that the inoculated microorganisms that colonized the rhizosphere incentivized the development of plants through complex interactions, such as those that occur between the root exudate derived from photosynthesis and other physiological processes of the plant, soil, microbiome, and population dynamics of the stalks (Singh et al., 2017). According to other studies, the bacteria act through a wide variety of mechanisms. Within these, the mineralization of organic material is accelerated, which facilitates mineral availability (Tilvikiené et al., 2018). With respect to this, we can speculate that the improved yield, achieved when using digestate and compost as inoculation media, can be partially attributed to the organic matter content of these media.

The results evidenced in this experiment coincide with those reported by Lopes et al. (2018), who observed a significant increase in the yield of Brachiaria brizanta under a silvopasture system, when inoculated with PGPR bacteria. Nonetheless, the changes noted in orchard grass yields are less than those reached by other grasses, according to descriptions by Rangel et al. (2014), who indicated that after inoculating wheat with PGPB bacteria, the achieved yield surpassed the control crop by up to $55 \%$.

The optimal temperature range for the growth of grasses in temperate climate is between $16-24{ }^{\circ} \mathrm{C}$ (Yao et al., 2011); however, in this study the leaf temperature values found with the infrared thermometer were above $25^{\circ} \mathrm{C}$; this condition could have caused stress to the crop and affected the yield.

The inoculation with bacteria promoted plant growth and an increase in number of stalks when compared to the control, and both variables are correlated with the yield (Hernández-Garay et al., 1997). In parallel, the accumulation of forage is correlated with the accumulation or storage of non-structural carbohydrates in the root, which constitute an important source of carbon for bacteria and for re-sprouting after defoliation (Benot et al., 2019).

The bacteria evaluated in this experiment have been reported as PGPB bacteria by different authors, and their benefits as phosphate solubilizers, nitrogen fixers, and siderophore synthesizers have been mainly evaluated in growth media and in vitro conditions (Rashid et al. 2012). Although techniques to measure in vitro microbial activity were not used in this work, the results found can be partially attributed to the effect of the bacteria and the inoculation medium. It is important to underline that the effect of PGPB bacteria varies considerably depending on the species, type of soil, plant species, environmental conditions, and soil microbiome with which the inoculated bacteria commonly compete (Armenta-Bojórquez et al., 2010).

\section{CONCLUSIONS}

The use of compost and digestate as inoculation media catalyze the effect of PGPB bacteria on the production of dry matter in orchard grass, and the inoculation of Microbacterium ginsengiterrae on the yield of orchard grass.

\section{ACKNOWLEDGMENTS}

To Laura J. García Barrera (M. in Sc.), for her support in the isolation and identification of the bacteria assessed in this study.

\section{REFERENCES}

Alori E.T., Dare M.O. \& Babalola O. O. (2017). Microbial inoculants for soil quiality and plant health. Sustainable Agriculture reviews 22: 281-308

Armenta-Bojórquez A. D., García-Gutiérrez C., Camacho-Báez R., Apodaca-Sánchez M. A., Gerardo-Montoya L. \& Nava-Pérez E. (2010). Biofertilizantes en el desarrollo agrícola de México. Ra Ximhai. 6(1): 51-56

Benot M-L., Morvan-Bertrand A., Mony C., Huet J., Sulmon S., Decau M-L., Prud'homme M-P. \& Bonis A. (2019). Grazing intensity modulates carbohydrate storage pattern in five grass species from temperate grasslands. Acta Oecologica. (95):108-115.

Castillo, E. G., Valles M. B. \& Jarillo, R. J. (2009). Relación entre materia seca presente y altura en gramas nativas del trópico mexicano. México. Técnica Pecuaria en México. 47(1): 79-92.

Grageda-Cabrera O. A., Díaz-Franco A., Peña-Cabriales J. J. \& VeraNuñez J. A. (2012). Impacto de los biofertilizantes en la agricultura. Revista Mexicana de Ciencias Agrícolas. 3(6): 1261-1274 
Hernández-Garay, A., Matthew, C. \& Hodgson, J. (1997). Effect of spring grazing management on perennial ryegrass and ryegrass-white clover pastures. 1. Tissue turnover and herbage accumulation. New Zealand. New Zealand Journal Agricultural Research. 40:25-35.

Lopes, M. J. S., Dias-Filho, M. B., Castro, T. H. R. \& Silva, G. B. (2018). Light and plant growth-promoting rhizobacteria effects on Brachiaria brizanta growth and phenotypic plasticity to shade. United Kingdom Grass and Forage Science. 73(2) 493-499.

McKenzie, B. A., Kemp, P. D., Moot, D. J., Matthew, C. \& Lucas, R. J. (1999). Environmental effects on plant growth and development. In: White James and Hodgson John editors. New Zealand Pasture and Crop Science. Auckland, New Zealand: Oxford University Press. 29-44.

Menna, V. S.; Menna, S. K.; Verna, J. P.; Kumar, A.; Aeron, A.; Mishra, P. K.; Bisht, J. K.; Pattanayak, A.; Navved, M. \& Dotaniya, M. L. (2017). Plant beneficial rhizospheric microorganism (PBRM) strategies to improve nutrients use effciency: A review. Netherlands. Ecological Engineering the Journal of Ecotechnology. 107:8-32.

Pérez-Montaño, F., Alías-Villegas, C., Bellogín, R. A., Del Cerro, P., Espuny, M. R., Jiménez-Guerrero, I. \& Cubo, T. (2014). Plant growth promotion in cereal and leguminous agricultural important plants: From microorganism capacities to crop production. Germany. Microbiological Research, 169 (56):325-336

Planes-Leyva M., Utria-Borges E., Calderón-Agüero J. O., Terry-Lamothe A. O., Figueroa-Santana I. \& Lores A. (2004). La biofertilización como herramienta biotecnológica de la agricultura sostenible. Revista Chapingo serie Horticultura. 10(1): 5-10.

Rangel, L. J. A., Ramírez, G. R. M., Cervantes, O. F., Mendoza, E. M., García, M. E. \& Rivera, R. J. G. (2014). Biofertilización de Azospirillum spp. y rendimiento de grano de maíz, sorgo y trigo. Argentina. Revista de la Facultad de Ciencias UNCUYO. 46(2):231-238.

Rashid, S., Charles, T. C. \& Glick, B. R. (2012). Isolation and characterization of new plant growth-promoting bacterial endophytes. Netherlands. Applied Soil Ecology. 61: 217-224.

SAS. User's Guide: Statistics (Version 9.0 ed.). Cary NC, USA: SAS Inst. Inc. (2002).

SigmaPlot. User's Guide (Versión 10.0). Systat software (2015).

Singh M V., Kumari M S., Prakash V J., Kumar A., Aeron A., Kumar M P., Kumar B J., Pattanayak A., Neveed M. \& Dotoniya M L. (2017). Plan beneficial rhizospheric microorganism (PBRM) strategies to improve nutrients use efficiency: A review. Ecological Engineering. 107: 8-12.

Tilvikiené, V., Slepetiené. A. \& Kadziuliené. (2018). Effects of 5 years of digestate application on biomass production and quality of cocksfoot (Dactylis glomerata L.). United Kingdom. Grass and Forage Science 73(1):206-2017.

Yao H., Bowman D. \& Shi W. (2011). Seasonal variations of soil microbial biomass and activity in warm- and cool-season turfgrass system. Soil Biology \& Biochemistry. 43(7):1536-1543.

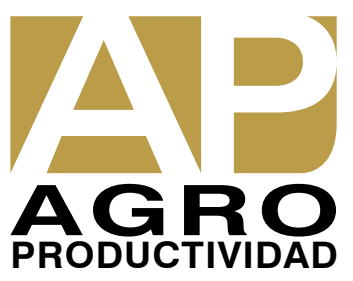

